\title{
Simultaneous infection with gammaherpes and influenza viruses enhances the host immune defense
}

\author{
L. ANČICOVÁ ${ }^{1 *}$, M. WÁGNEROVÁ ${ }^{1 *}$, J. JANULÍKOVÁ ${ }^{2}$, A. CHALUPKOVÁ ${ }^{1}, Z^{2}$. HRABOVSKÁ ${ }^{1}$, \\ F. KOSTOLANSKÝ, E. VAREČKOVÁ ${ }^{2}$, J. MISTRÍKOVÁ ${ }^{1,2^{*}}$
}

${ }^{1}$ Faculty of Natural Sciences, Department of Microbiology and Virology, Comenius University, Mlynská dolina, Ilkovičova 6, 84215 Bratislava 4, Slovak Republic; ${ }^{2}$ Institute of Virology Slovak Academy of Sciences, Dúbravská cesta 9, 84505 Bratislava, Slovak Republic

Received May 4, 2015; revised July 7, 2015; accepted October 2, 2015

\begin{abstract}
Summary. - We have studied the impact of simultaneous infection of mice with murine gammaherpesvirus (MHV) and influenza A virus (IAV) on the immune response and pathogenesis of both infections. After a persistent MHV-68 herpesviral infection had been established, the same mice were super-infected with IAV. Individual parameters of MHV infection (viral DNA detection in organs and blood) and numbers of leukocytes in lungs and spleens were determined. With regard to the assumed reactivation of MHV-68 (mainly in lungs, spleen, thymus and peritoneal exudate cells) we focused our attention on the detection of transcripts, typical either for lytic infection (ORF50) and/or for latency (ORF73). Herpesviral DNA was detected in above mentioned organs in several intervals during the acute phase of IAV co-infection, but the expression of monitored transcripts was lower, i.e. it has decreased. Though the reason for such limited expression during acute influenza superinfection remains unclear, it is unambiguous that lower MHV-68 expression was detected in lungs and peritoneal exudate cells (PECs) from $3^{\text {rd }}$ to $10^{\text {th }}$ day after co-infection with IAV. Furthermore, our study showed that the ongoing gammaherpesvirus latency in co-infected mice affected the number of cytotoxic T-lymphocytes and neutrophils during the acute IAV infection and lowered their deviations from that of non-infected mice. Therefore, we suppose that co-infection with herpes and influenza viruses could be mutually beneficial for the host by promoting its defense against both viruses.
\end{abstract}

Keywords: murine herpesvirus; influenza A virus; co-infection; latency

\section{Introduction}

Most hosts, including humans, are often concurrently infected with multiple pathogens, frequently by herpesviruses. Hosts that are immunologically challenged by one infection often show increased susceptibility to a second infective agent. This has been demonstrated with various groups of pathogens, including parasites, protozoa, bacte-

"Corresponding author. E-mail: virumis@savba.sk; phone: +421-260296485. "These authors equally contributed to this project.

Abbreviations: IAV = influenza A virus; MHV-68 = murine gammaherpesvirus 68; EBV = Epstein-Barr virus; p.i. = post infection; $\mathrm{DBC}(\mathrm{s})=$ differential blood count $(\mathrm{s}) ; \mathrm{LCMV}=$ lymphocytic choriomeningitis virus; $\mathrm{PECs}=$ peritoneal exudate cells ria, and viruses (Thakar et al., 2012; Griffiths et al., 2011). On the other hand, interaction between several infectious agents may lead to altered immune responses, leading to heterologous immunity or cross-protective immunity. Several research teams in the last few years investigated the double co-infection, especially its impact on host immunity and overall course of infection (Florescu et al., 2011; Smith et al., 2013). In previous studies it has been shown that mice infected with certain groups of herpesviruses, such as mouse cytomegalovirus and murine gammaherpesvirus (MHV), developed a resistance to intracellular bacterial pathogens such as Listeria monocytogenes and Yersinia pestis. These data evoke a speculation that under certain conditions harboring herpesviruses may be a survival benefit (due to mechanisms) which tends to be host species-specific and which had been formed by co- 
evolution within their hosts during a long period of time (Barton et al., 2007).

Humans become infected with multiple herpesviruses during childhood. After clearance of the acute (stage of) infection, herpesviruses enter a dormant state known as latency. Latency persists for the life of the host and it is presumed to be parasitic, as it leaves the individual at risk for subsequent viral reactivation and diseases (Welsh et al., 2010). EpsteinBarr virus (EBV) is a human gammaherpesvirus with high worldwide prevalence in adults (up to $90 \%$ ), which is able to establish life-long persistent infection in resting memory B cells in its host. This virus is maintained in a balance between viral homeostasis on one side and antiviral defense of the immune system on the other side. Latent EBV infection is commonly associated with human cancer, in particular, with lymphoid malignancies and/or nasopharyngeal carcinoma (Arfelt et al., 2015; Hopwood and Crawford, 2000; Mutalima et al., 2008; Rickinson and Kieff, 2007). Childhood infection with EBV is often subclinical, while the same infection is frequently symptomatic in adolescents and adults and is manifested as infectious mononucleosis (IM). Some studies confirm that cross-reactive influenza virus-specific $\mathrm{CD} 8^{+} \mathrm{T}$ cells contribute to lymphoproliferation of EBV-associated IM (Clute et al., 2005). However, the cross-reactive cells that dominate this response have low affinity for the virus antigen-expressing cells and cannot control the infection adequately. Despite the apparent advantage of a pre-existing immune repertoire, the net result is immunopathology. This effect may underlie the observation that some infections, such as measles, mumps, chickenpox, and EBV, have more severe consequences in teenagers and young adults than they do in young children (Welsh and Fujinami, 2007; Sharma and Thomas, 2014).

MHV-68 is a natural rodent pathogen that is structurally, biologically, and genetically related to human herpesviruses. Intranasal infection of mice with MHV-68 causes an acute respiratory infection that is rapidly resolved, followed by the establishment of a life-long latency in B-lymphocytes, macrophages and dendritic cells. Because of its relatedness to human gammaherpesviruses, experimental MHV-68 infection provides a natural model for the study of $\gamma$-herpesvirus pathology and host immunity in vivo (Blaškovič et al., 1980; De Lima et al., 2005; Nash et al., 2001; Kúdelová and Rajčáni, 2007).

The research of double infection is important to clarify the mortality among previously clinically healthy and/or young individuals due to influenza infection, and such studies are highly relevant because most of the population is latently infected with at least one of the two gammaherpesviruses. Understanding how co-infection can alter the possible overwhelming immune response, cytokine storm, inflammatory immunopathology or potential cross-protection and heterologous immune response could be critical for the develop- ment of novel strategies for the prevention and treatment of these infections.

Saito et al. (2013) demonstrated that MHV-68 latency results in accelerated influenza viral clearance at early time points, leading to lower influenza viral loads and decreased inflammatory pathology in the lungs. Further, they investigated differences in numbers of lung inflammatory cells and suggested the importance of $\mathrm{CD}^{+} \mathrm{T}$ cells and the number of neutrophils in antiviral immunity (Saito et al., 2013). Other study provided evidence that latently infected mice had lower levels of IFN- $\gamma$ in lung homogenates and that MHV- 68 viral load in the spleen were unaltered by influenza infection (Hardisty et al., 2013). Recent studies with MHV-68 and lymphocytic choriomeningitis virus (LCMV) demonstrated that ongoing gammaherpesvirus latency affected the number of $\mathrm{CD}^{+} \mathrm{T}$ cells during acute LCMV infection (Barton et al., 2014). Other research team found that helminth infection reactivated murine gammaherpesvirus infection in vivo (Reese et al., 2014). Yager et al. proved that early MHV-68 latency conferred protection against bacterial infection, but it was shown that the effect was transient (Yager et al., 2009).

The aim of the current study is to contribute to the understanding how acute viral infection influences pathogenesis and latency control of persistent infection. Recent research studies hypothesized that MHV-68 latency would provide the host with protective immunity against influenza virus infection (Saito et al., 2013; Hardisty et al., 2013). In this study we did not focus on understanding the mechanism underlying the immunity to the influenza virus, but - here we attempted to decipher whether the acute influenza infection can alter the ongoing latent MHV-68 infection. We assumed that during co-infection, ability of a pathogen to influence the immune response against another pathogen can work both ways, and that an acute respiratory viral infection could modulate many parameters of lytic and/or latent MHV-68 infection. Our results provide evidence that an acute respiratory viral infection impacts the host immune response to a latent gammaherpesviral infection.

Our findings can broaden the knowledge about gammaherpesvirus pathogenesis and enlighten possible risks of double infection that can often occur in reality. In clinical practice latent infection with human herpesviruses EBV and Kaposi's sarcoma associated herpesvirus, even when undeterminable, may play a hitherto unrecognizable role in affecting the immune response to respiratory pathogens like influenza virus.

\section{Material and Methods}

Cells, viruses and mice. Vero cells and NIH 3T3 cells were maintained in Dulbecco's modified Eagle's medium (DMEM) supplemented with $9 \%$ of heat-inactivated fetal bovine serum (FBS), 
glutamine, penicillin and streptomycine. MHV-68 stock for in vitro and in vivo experiments was prepared by virus propagation on NIH 3T3 cells, while titers of infectious viruses were determined by plaque assay using Vero cells. Influenza A/Mississippi/1/85 $(\mathrm{H} 3 \mathrm{~N} 2)$ strain was propagated in the allantoic cavity of embryonated chicken eggs and adapted on $\mathrm{Balb} / \mathrm{c}$ mice as done previously (Fislová et al., 2009).

Animal experiments. Female 6-8-week-old inbred BALB/c mice were supplied by the Faculty of Veterinary Medicine, Brno, Czech Republic. Mice were intranasally infected with $2 \times 10^{4} \mathrm{PFU}$ of MHV-68 per mouse in total inoculum volume of $20 \mu \mathrm{l}$, under light anesthesia. Forty-five days after herpesviral infection mice were intranasally infected with human mouse adapted influenza virus A/Mississippi/1/85/M9/E2 (H3N2). For infection a sublethal dose: $0.4 \mathrm{LD}_{50}$ (78.8 PFU/mouse) was used, in volume of $40 \mu \mathrm{l}$. Control group of mice received intranasally $20 \mu$ of phosphate buffered saline (PBS). Three experimental groups of 64 animals and one control group of 12 mice were set up (Table 1). Mice were killed by cervical dislocation under anesthesia in six different time points and various organs collected from mice were analyzed. All animal experiments were performed according to the European Union standards and fundamental ethical principles including animal welfare requirements were respected. All experiments were done with the approval of State Veterinary and Food Administration of the Slovak Republic (2937/10-221).

Blood sample analysis. Blood samples were taken from sinus orbitalis at different time points post infection for serum preparation and examination of leukocytes. The obtained sera were inactivated for $30 \mathrm{~min}$. at $56^{\circ} \mathrm{C}$ and stored at $-20^{\circ} \mathrm{C}$ until used in virus neutralization assay. Blood samples were mixed with heparin (final concentration of 2-4 U/ml) and stained with Turck's solution to determine the total leukocyte count microscopically. Heparinized blood was used also for blood smears, which were stained with MayGrünwald solution (for $10 \mathrm{~min}$.) and Giemsa-Romanowski solution (for $15 \mathrm{~min}$.) and differential blood cell count was evaluated.

Virus-neutralization assay. 2-fold dilutions of inactivated immune sera were incubated with 1000 PFU of MHV-68. After 30 min incubation at $37^{\circ} \mathrm{C}$, virus-serum mixtures were inoculated onto Vero cell monolayers. The last dilution of serum that was able to prevent virus infection in cell culture was considered as the titer of virus-neutralization antibodies.

Detection of viral genome and transcripts. Total DNA was extracted from $300 \mu$ of heparinized blood and of organ homogenates using

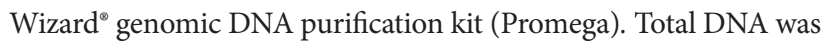
used as a template in nested PCR using M7 primers: M7 (forward 1): CTCGAACAACAATCCCACTACA and M7 (reverse 1): CGTAT CCAAAGCAGGGTAGAAA, M7 (forward 2): GCCCAAAA TGGTGAGAGTGTA and M7 (reverse 2): GGTGGGTTCATC TTCCTGATT. Total RNA was extracted from peritoneal exudate cells (PECs), lungs and spleen of MHV-68 infected and herpes + influenza co-infected mice. Lungs and spleen were homogenized using $70 \mu \mathrm{m}$ nylon cell strainers (BD Falcon), $1 \mathrm{ml}$ TRI Reagent ${ }^{\bullet}$ (Sigma-Aldrich) was added and extraction was carried out according to manufacturer's instructions. Complementary DNA was synthesized from total RNA by Revert aid first strand cDNA synthesis kit (Thermo Scientific). Mouse $\beta$-actin was used as an internal control, using primers: Act (forward): TCCTCCCTGGAGAAGAGCTA and Act (reverse): ACATCTGCTGGAAGGTGGAC. Thus verified cDNA was used as a template in nested PCR in which transcripts of ORF 50 (immediate-early) and ORF 73 (latent) were analyzed. Sets of gene-specific primers used for nested PCR were as follows: ORF73 (forward 1): TAGTACCTTCTACGCTGCTG and ORF73 (reverse 1): GTAGGTGCTTCAACAAACCA, ORF73 (forward 2): CCAAG GGTAAACAGCTAACTG and ORF73 (reverse 2): CCTTCATCAC CAGTACATGAG, ORF50 (forward 1): CCACCTGATCAAATAT GCCA and ORF50 (reverse 1): TGTGGGTTTCTTGTTTGGAC, ORF50 (forward 2): TGGCATATCCAGAGAAGTTGAG and ORF50 (reverse 2): TGGGAGTAGGTATGTAGCTCTG.

Flow cytometry. Spleens were harvested and mechanically dispersed into a single cell suspension using $70 \mu \mathrm{m}$ nylon cell strainers, and ammonium chloride lysis buffer was used to lyse erythrocytes. Single cell suspensions of lungs were prepared by dispersing. Lungs were minced in supplemented PBS containing 0.1\% type A collagenase (Sigma-Aldrich) for $30 \mathrm{~min}$ at $37^{\circ} \mathrm{C}$. Cells were fixed on ice for $20 \mathrm{~min}$. with parafolmaldehyd in supplemented versen solution containing $1 \%$ fetal bovine serum and stained with the indicated antibodies: rat monoclonal to CD3 epsilon PE (Abcam) or anti-mouse CD3e PE (eBioscience); anti-mouse CD4PerCP - Cy 5.5 (eBioscience); anti-mouse CD8a/Lyt - 2 - FITC (BECKMAN COULTER); anti-mouse CD19 FITC (CD5) (PROIMMUNE) (CD19 PE-Cy5 (6D5); anti-mouse CD45 PE (eBioscience) and rat anti-mouse Ly-6G FITC (BD Pharmingen) on ice for 20-30 min. Cells were analyzed using Guava easyCyte ${ }^{\mathrm{TM}} \mathrm{HT}$ system (Millipore) and data generated were analyzed by software InCyte 2.5 .

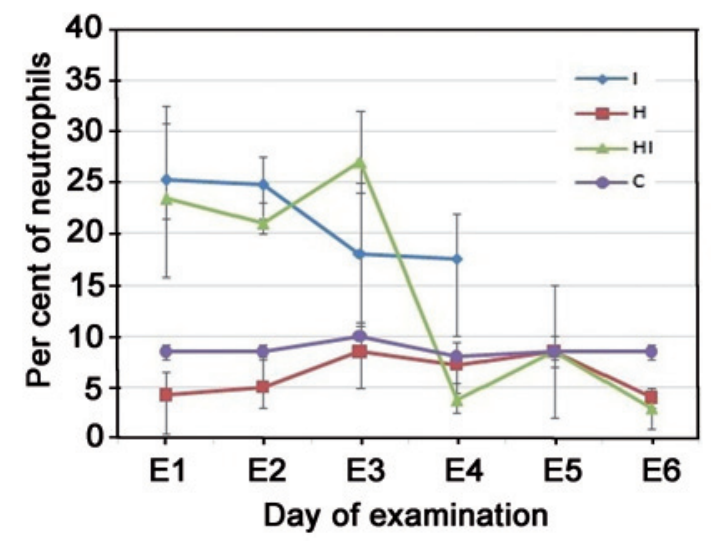

Fig. 1

Percentage of neutrophils from a total number of leukocytes (100\%) in peripheral blood of persistently infected mice after co-infection with influenza A virus

The value for each group represents the mean \pm standard deviation for four mice. $\mathrm{I}=\mathrm{IAV}$ infected mice; $\mathrm{H}=\mathrm{MHV}-68$ infected mice; $\mathrm{HI}=\mathrm{IAV}$ and MHV-68 co-infected mice; $\mathrm{C}=$ control mice; E1-E6 = days of examination (see Table 1). 
Table 1. Time schedule describing days of examination. Four infected mice and 2 control mice per group were used for analysis at each time point

\begin{tabular}{|c|c|c|c|c|c|}
\hline \multirow[b]{2}{*}{$\begin{array}{l}\text { Day } \\
\text { of experiment }\end{array}$} & \multirow[b]{2}{*}{$\begin{array}{c}\text { Day } \\
\text { of examination }\end{array}$} & \multicolumn{4}{|c|}{ Group of mice } \\
\hline & & $\begin{array}{c}\mathrm{H} \\
\mathrm{MHV}^{-68^{*}}\end{array}$ & $\begin{array}{c}\text { I } \\
\text { A/Miss }\end{array}$ & $\begin{array}{c}\text { HI } \\
\text { MHV-68 } \\
\end{array}$ & $\begin{array}{c}\text { C } \\
\begin{array}{c}\text { Mock infection } \\
\text { (control) }\end{array} \\
\end{array}$ \\
\hline Day 48 & E1 & $=48 \mathrm{dpi}$ & $=3 \mathrm{dpi}$ & $=48 \mathrm{dpi}$ with MHV-68 =3 dpi with A/Miss & $=48 \mathrm{dpm}$ \\
\hline Day 51 & E2 & $=51 \mathrm{dpi}$ & $=6 \mathrm{dpi}$ & $=51 \mathrm{dpi}$ with MHV-68 =6 dpi with A/Miss & $=51 \mathrm{dpm}$ \\
\hline Day 55 & E3 & $=55 \mathrm{dpi}$ & $=10 \mathrm{dpi}$ & $=55$ dpi with MHV- $68=10$ dpi with A/Miss & $=55 \mathrm{dpm}$ \\
\hline Day 105 & E4 & $=105 \mathrm{dpi}$ & $=60 \mathrm{dpi}$ & $=105 \mathrm{dpi}$ with MHV- $68=60 \mathrm{dpi}$ with A/Miss & $=105 \mathrm{dpm}$ \\
\hline Day 180 & E5 & $=180 \mathrm{dpi}$ & ND & $=180$ dpi with MHV-68 =135 dpi with A/Miss & $=180 \mathrm{dpm}$ \\
\hline Day 270 & E6 & $=270 \mathrm{dpi}$ & ND & $=270$ dpi with MHV-68 $=225 \mathrm{dpi}$ with $\mathrm{A} / \mathrm{Miss}$ & $=270 \mathrm{dpm}$ \\
\hline
\end{tabular}

A/Miss = A Mississippi/1/85 (H3N2); dpm = day post mock-infection; *Infected on day 1; * Infected on day 45.

\section{Results}

\section{Clinical symptoms of co-infected and mono-infected mice}

Mice were infected with murine gammaherpesvirus by intranasal inoculation and after forty-five days, the same mice were challenged intranasally with sublethal dose of influenza virus.

Mice co-infected with MHV-68 and IAV were 55 days post MHV-68 infection / 10 days post infection (p.i.) with IAV very slim, had hyperaemic lungs, their intestines were empty and they had bristly fur. Forty-eight days later, all mice reached the standard weight without any clinical symptoms of the disease. At the $2^{\text {nd }}$ interval, i.e. 6 days after IAV infection, the enlargement of thymuses of co-infected mice were observed in comparison to mice infected with only MHV-68. Mice infected with MHV-68 had 270 days p.i. hepatosplenomegaly and they were fatter than MHV-68 and IAV co-infected mice. It was evident that co-infected mice had less fat, there was no food in their stomach and intestine, and all of double infected mice had post-inflammatory necrotic lesion in lungs.

Co-infection increased the number of neutrophils in blood but did not affect the level of MHV-68 neutralizing antibodies

Based on comparison of differential blood counts (DBCs) of mice infected with MHV-68 alone and of co-infected mice we

Table 2. Percentage of lungs positive for ORF50 expression

\begin{tabular}{cccccccc}
\hline & & E1 & E2 & E3 & E4 & E5 & E6 \\
\hline \multirow{2}{*}{ ORF50 } & H & 50 & 50 & 25 & 25 & 0 & 25 \\
& HI & 0 & 0 & 25 & 0 & 0 & 0 \\
\hline
\end{tabular}

Expression of ORF50 and ORF73 genes in lungs. E1-E6 = days of examination (see Table 1). H-MHV-68 infected mice; HI-IAV and MHV-68 co-infected mice. Numbers represent percentage positive for ORF50 expression (0-100\%). ascertained that the most significant differences were observed in levels of lymphocyte and neutrophil subpopulations of leukocytes. Percentage of lymphocytes in DBC after a single infection of mice with MHV- 68 was by $20 \%$ higher in some time points in comparison to mice infected with influenza A virus only or to co-infected mice. Later after infection, on the $60^{\text {th }}-225^{\text {th }}$ day post infection with IAV, the number of lymphocytes in blood of co-infected mice was higher than in MHV-68 infected mice.

Based on DBCs, our results confirmed the importance of neutrophils function during influenza virus infection, as shown in the control group of mice. Throughout the acute IAV infection the amount of neutrophils in peripheral blood of co-infected mice increased 5-fold in comparison with herpes mono-infection, with maximum on $10^{\text {th }}$ day after IAV infection. When mice cleared influenza infection, the percentage of neutrophils decreased dramatically (Fig. 1).

We didn't observe any significant changes in titers of virus-neutralizing antibodies against $\mathrm{MHV}-68$ during persistent herpesvirus infection in comparison with the MHV-68 and IAV co-infection. Titers of virus-neutralizing antibodies against MHV-68 decreased proportionally to the length of primary herpes infection and ranged from 32 to 4 .

Detection of herpesviral DNA in organs and reduction of ORF50 and ORF73 expression in the lungs and PECs

We demonstrated the presence of herpesviral DNA by nested PCR in all examined organs almost throughout the

Table 3. Percentage of lungs positive for ORF73 expression

\begin{tabular}{cccccccc}
\hline & & E1 & E2 & E3 & E4 & E5 & E6 \\
\hline \multirow{2}{*}{ ORF73 } & H & 50 & 50 & 50 & 25 & 0 & 0 \\
& HI & 25 & 0 & 0 & 25 & 0 & 0 \\
\hline
\end{tabular}

Expression of ORF50 and ORF73 genes in lungs. E1-E6 = days of examination (see Table 1). H-MHV-68 infected mice; HI-IAV and MHV-68 co-infected mice. Numbers represent percentage positive for ORF73 expression (0-100\%). 


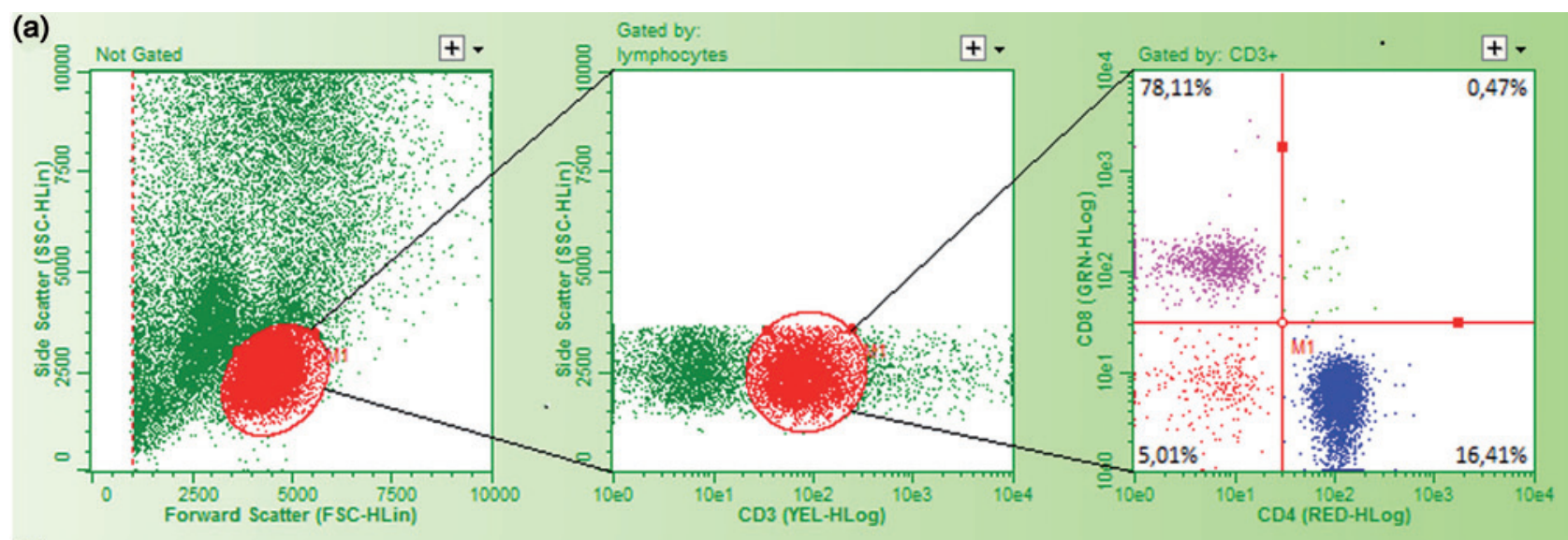

(b)
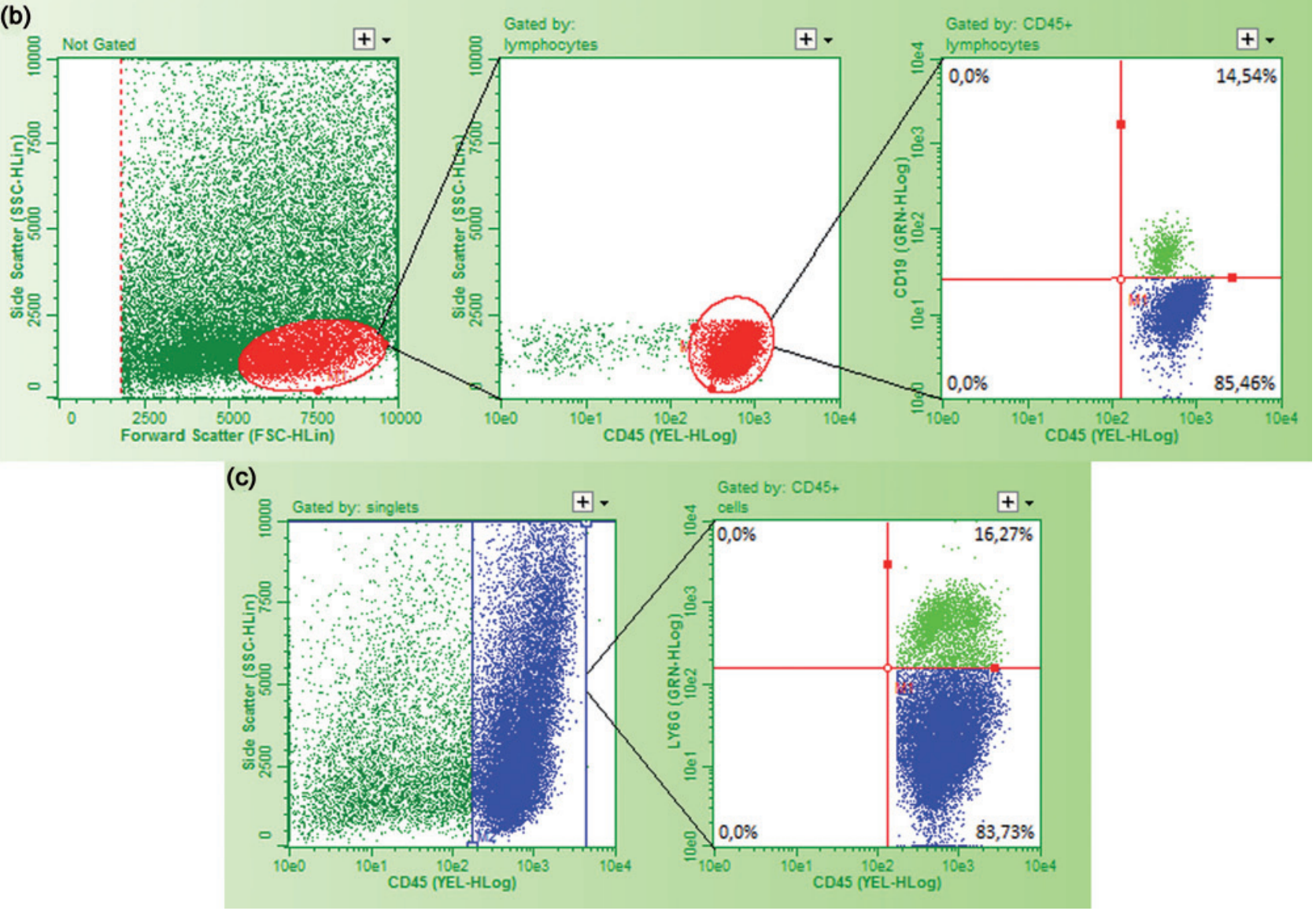

Fig. 2

Phenotypic analysis

(a) Phenotypic analysis of T-lymphocytes in lungs. Representative dot plot, as well as the gating strategy for identification and quantification of T-lymphocytes. Diverging lines indicate the sequence of gating. The gates for each dot plot are presented on the top of each box. The positive expression of markers compared to cells without antibody staining. Purple color represents the $\mathrm{CD} 3^{+} \mathrm{CD} 4^{+} \mathrm{CD} 8$ population whereas blue represents $\mathrm{CD} 3^{+} \mathrm{CD} 8^{+} \mathrm{CD} 4$ population. (b) Phenotypic analysis of B-lymphocytes in lungs. Representative dot plot, as well as the gating strategy for identification and quantification of B-lymphocytes. Bright light green color represents the $\mathrm{CD} 19^{+} \mathrm{CD} 45^{+} \mathrm{B}$ cell population whereas blue represents $\mathrm{CD} 19^{-} \mathrm{CD} 45^{+}$lymphocyte population. (c) Phenotypic analysis of neutrophils in lungs. Representative dot plot, as well as the gating strategy for identification and quantification of neutrophils. Bright light green color represents the $\mathrm{Ly} 6 \mathrm{G}^{+} \mathrm{CD} 45^{+}$neutrophil population whereas blue represents $\mathrm{Ly} 6 \mathrm{G}-\mathrm{CD}_{4} 5^{+}$leukocyte population.

whole duration of the experimental infection with both viruses. We further examined the expression of ORF50 and ORF73 genes as markers of lytic infection and latency, respectively (Polčicová et al., 2008). Samples from lungs, 

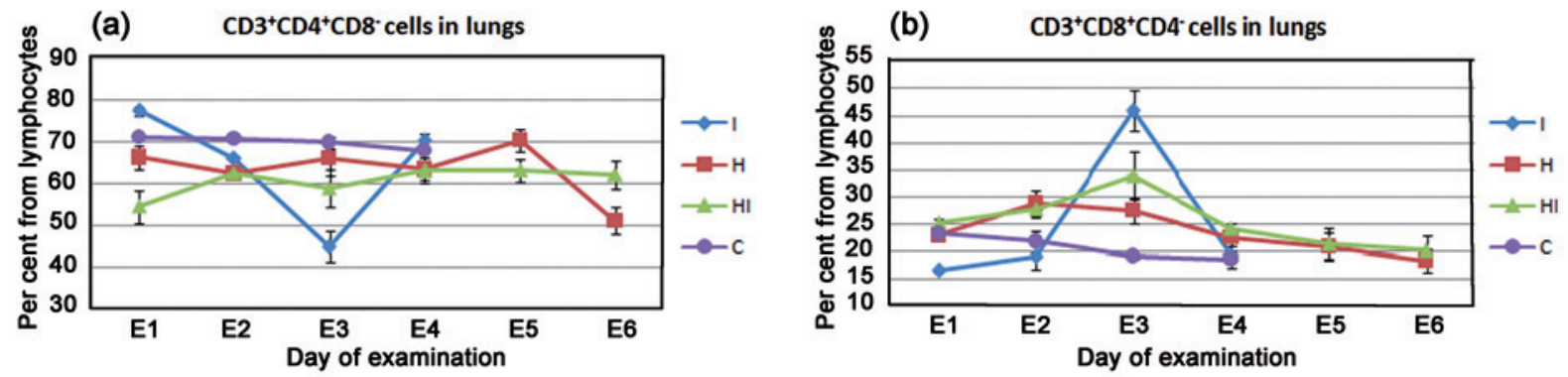

(c)

CD19+CD45+ cells in lungs
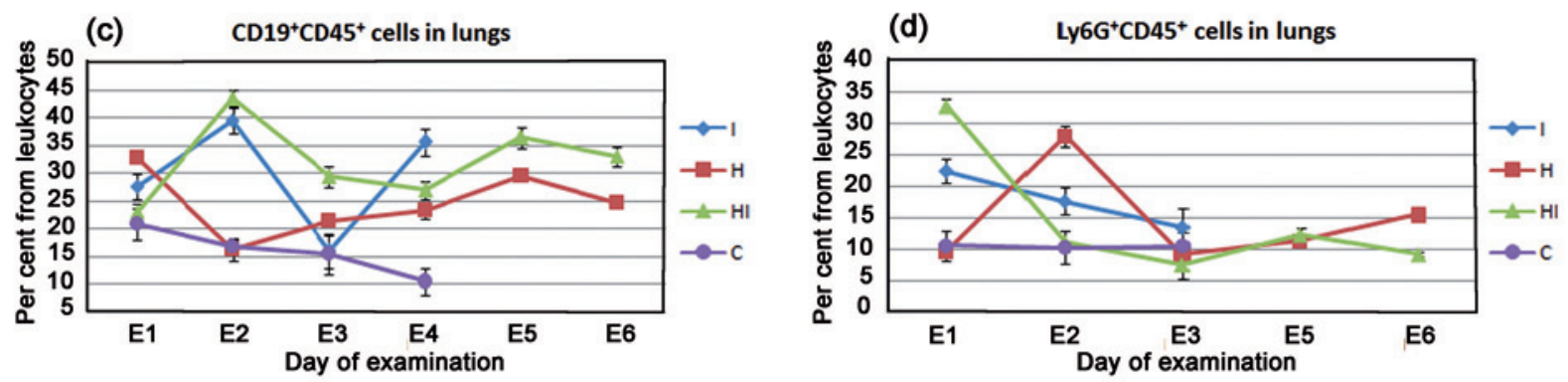

Fig. 3

Cellular profiles depict percentage of (a) $\mathrm{CD}^{+} \mathrm{CD}^{+} \mathrm{CD} 8$, (b) $\mathrm{CD}^{+} \mathrm{CD}^{+} \mathrm{CD} 4$, (c) $\mathrm{CD}^{+} 9^{+} \mathrm{CD}^{2} 5^{+}$and (d) $\mathrm{Ly}_{6 \mathrm{G}} \mathrm{CD}^{+} 5^{+}$cells in lungs collected from mice at the indicated time points after virus challenge and were determined using flow cytometry analysis

(a), (b) are determined as a percentage from lymphocytes population, (c), (d) as a percentage from leukocytes. E1-E6 = days of examination (see Table 1).

spleens, thymuses and PECs were obtained according to the scheme in (Table1). Since MHV-68 establishes latency in lungs, we focused on detection of ORF50 and ORF73 expression during the secondary acute respiratory infection, in order to determine, whether influenza infection can affect herpesvirus reactivation from latency. We did not observe MHV-68 reactivation, but we recorded decreased expression of ORF50 and ORF73 during co-infection in lungs and this effect lasted during first two intervals for ORF50 and first three time points for ORF73 (Table 2, 3). The same phenomenon was detected in PECs, but MHV-68 expression was not altered in thymus and spleen. After influenza infection was overcome at the later time points (E4-E6) we did not see obvious differences between individual experimental groups of mice. What is responsible for the altered regulation of herpesvirus expression remains hypothetical.

Co-infection affected the number of leukocyte subpopulations in lungs but not in spleen

We observed that fifty-five days after MHV-68 and 10 days after IAV infection, the pool of $\mathrm{CD}^{+} / \mathrm{CD} 8^{-} \mathrm{T}$ cells in lungs of double-infected mice decreased in comparison with the single herpesvirus infection (Fig. 2a, 3a). On the other hand, the pools of $\mathrm{CD}^{+} / \mathrm{CD} 4-\mathrm{T}$ and $\mathrm{CD} 19^{+} / \mathrm{CD} 45^{+} \mathrm{B}$ cells in lungs of double-infected mice increased when compared to single MHV-68 infection (Fig. 2b, 3b,c). Thus we found that $\mathrm{CD}^{+} \mathrm{T}$ cells expanded during the acute phase of influenza infection. This was in agreement with the effective elimination of vRNA of influenza virus from mouse lungs and with the decrease of titer of the infectious IAV in lungs (results not shown). It is known that $\mathrm{CD}^{+} \mathrm{T}$ cells are critical for the clearance of intracellular pathogens, including viruses and certain bacteria (Welsh et al., 2010). We showed that ongoing gammaherpesvirus latency affected the number of cytotoxic T-lymphocytes during the acute influenza infection, which resulted in more effective clearance of IAV.

Examination of levels of neutrophils, showed a more rapid reduction of $\mathrm{Ly} 6 \mathrm{G}^{+} / \mathrm{CD} 45^{+}$neutrophils in lungs of doubleinfected mice during the IAV co-infection, as compared to IAV mono-infected mice. The peak of number of neutrophils in lungs of co-infected mice was on the $3^{\text {rd }}$ day after IAV infection and their percentage was about $48.8 \%$ lower than in mice infected with IAV only (Fig. 2c, 3d). On the other hand, the relative amount of $\mathrm{Ly} 6 \mathrm{G}^{+} / \mathrm{CD} 45^{+}$neutrophils in the spleens of double infected mice, in comparison to mice solely infected with herpesvirus, was increased (Fig. 4d). No other notable differences between the investigated parameters were found in the spleen (Fig. 4a, b, c). Taken together, these results demonstrated that ongoing latent MHV-68 infection in co-infected mice affected the number of neutrophils during acute IAV infection. 
(a)

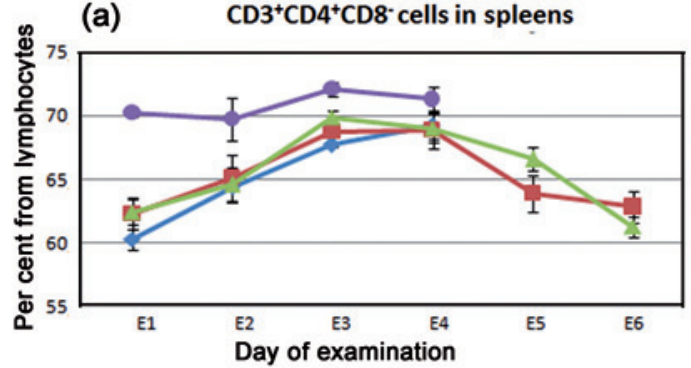

(c)

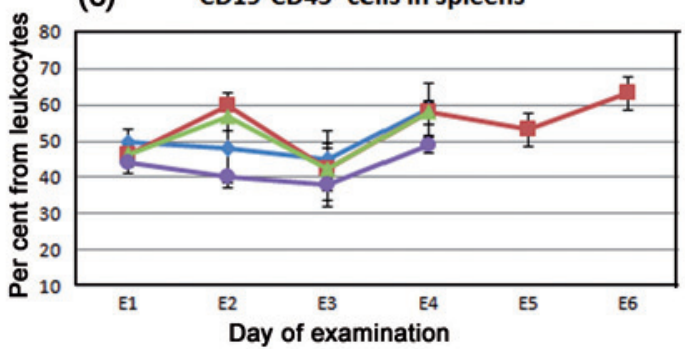

(b) $\mathrm{CD}^{+} \mathrm{CD}^{+} \mathrm{CD} 4$ cells in spleens
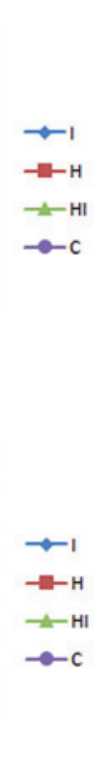

(d) $\mathrm{Ly}^{6} \mathrm{G}^{+} \mathrm{CD} 45^{+}$cells in spleens
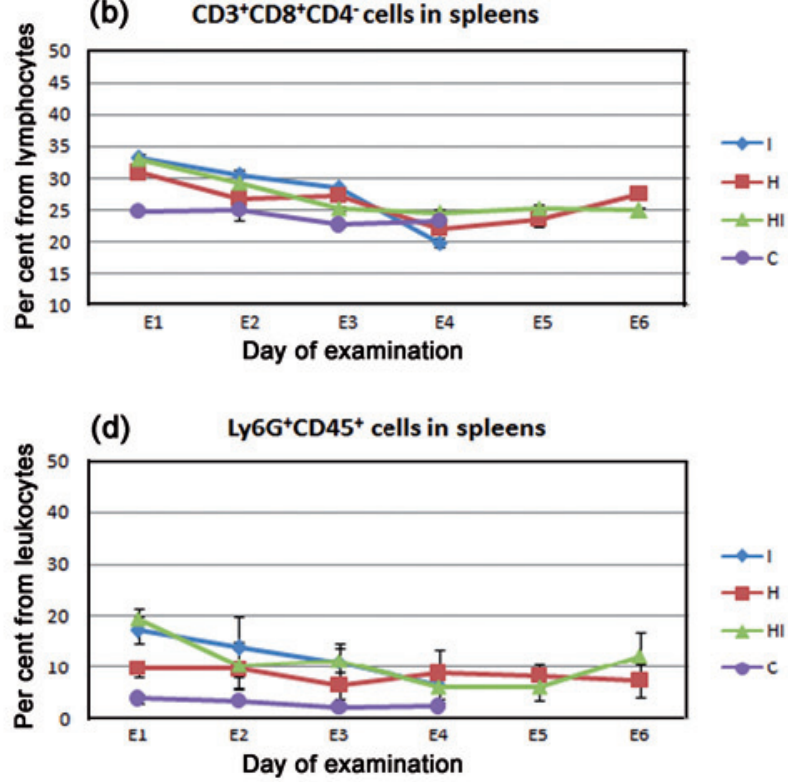

Fig. 4

Cellular profiles depict the percentage of $(\mathrm{a}) \mathrm{CD}^{+} \mathrm{CD}^{+} \mathrm{CD} 8$, (b) $\mathrm{CD3}^{+} \mathrm{CD}^{+} \mathrm{CD} 4$, (c) $\mathrm{CD}^{+} 9^{+} \mathrm{CD}^{+} 5^{+}$and $(\mathrm{d}) \mathrm{Ly} 6 \mathrm{G}^{+} \mathrm{CD} 45^{+}$cells in spleens collected from mice at the indicated time points after virus challenge and were determined using flow cytometry analysis

(a), (b) are determined as a percentage from lymphocyte population, (c), (d) as a percentage from leukocytes. E1-E6 = days of examination (see Table 1).

\section{Discussion}

Simultaneous co-infection or super-infection of hosts, including humans, with multiple parasite species is a common event in the natural environment (Brooker et al., 2012). Infections with different infecting agents can alter the immune response against each parasite and the abundance or persistence of the infection within the host. Such alteration of the immune response and change of infection course of the unrelated pathogen by the immune memory response caused by previously encountered pathogens is called heterologous immunity. It can lead to enhanced or diminished protective immunity and can alter immunopathology. In previous studies it was found, that infections with Bacillus Calmette-Guérin (BCG), IAV, LCMV, mouse cytomegalovirus and Pichinde virus all confer a level of protective immunity against vaccinia virus (Selin et al., 1998; Mathurin et al., 2009; Chen et al., 2003).

Nearly $90 \%$ of humans are latently infected with herpesviruses that, after clearance of acute infection, produce little infectious virus and often cause no overt disease. Like the human gammaherpesviruses EBV and Kaposi's sarcoma associated herpesvirus, MHV-68 establishes lifelong latency. Studies in this model system revealed that the latent MHV-68 can be reactivated in vivo by the secondary infection with parasitic helminths causing increased production of interleukin 4 .
On the other hand, INF- $\gamma$ inhibits MHV-68 replication and reactivation and controls persistent replication in vivo (Reese et al., 2014). Persistent infections, however, can lead to chronic inflammation (Cárdenas-Mondragón et al., 2013).

IAV-infected individuals often become co-infected with a bacterial pathogen and, consequently, morbidity and mortality significantly increase. The host plays a key role in better understanding of the way of interaction of these pathogens with each other (Smith et al., 2013).

Three possible points of view can be discussed regarding the triangle: host - persistent infection and the acute infection. First consideration is from the view of the host, whose aim is to suppress the acute infection, restrain the latent infection and possible reactivation and constrain the immune response to avoid the harmful immunopathology. The second interpretation is from point of view of latent virus that seeks (needs) to ensure such conditions, which allow it to persist in the host without its lethal damage (Fujinami et al., 2006). And the last one is the viewpoint of the virus causing acute infection, which aim is to replicate effectively and to spread to another hosts. There is no comprehensive understanding of the immune responses during co-infections and it is unclear how the systemic and local defense mechanisms interact (Thakar et al., 2012).

In the present study we focused mainly on the second view mentioned above. We investigated the effect of the 
acute influenza infection on the course of long-term chronic herpesviral infection and its capability to influence reactivation of the latent virus. We performed our research using mouse in vivo model with maintained persistent infection of MHV-68 followed by the acute infection with IAV. Several clinical symptoms were observed in co-infected mice during the chronic infection with MHV-68.

In all investigated parameters throughout the duration of co-infection we observed the same trend 55 days p.i. with MHV-68 / 10 days p.i. with IAV mice, namely the ability to overcome double viral load and all parameters monitored in co-infected mice leveled with values of herpes monoinfected animals.

As for acute influenza infection, we demonstrated that $\mathrm{CD} 8^{+} \mathrm{T}$ cells expanded and cleared IAV infection earlier. This observation is in agreement with previously published observations that ongoing gammaherpesvirus latency affects the number of memory cytotoxic T-lymphocytes during the acute influenza infection (Saito et al., 2013). The increase of $\mathrm{CD} 8^{+} \mathrm{T}$ cells occurs to the detriment of the number of the $\mathrm{CD} 4^{+} \mathrm{T}$-lymphocytes. $\mathrm{CD} 8^{+} \mathrm{T}$ cells are also considered a key player in the prevention of herpesviral reactivation during an acute heterologous viral infection (Sharma and Thomas, 2014). Taken together, we can conclude that the number of lymphocytes in peripheral blood, as well as $\mathrm{CD}^{+} / \mathrm{CD} 4$ $\mathrm{T}$ cells and $\mathrm{CD} 19^{+} / \mathrm{CD} 45^{+} \mathrm{B}$ cells in lungs of co-infected animals were increased in comparison with mono-infected mice which can lead to higher production of IFN- $\gamma$ and antibodies, resulting in stimulation of the immune system. Thus, it can explain a more effective suppression of IAV replication and prevention of herpesvirus reactivation from latency.

An important role of $\mathrm{CD}^{+} / \mathrm{CD}^{-} / \mathrm{CD} 8^{-} \mathrm{T}$ cells in lungs of co-infected mice during the first days of acute IAV infection can be also assumed, since on day 3 after IAV infection their percentage was 2.5 -fold or 2-fold higher in co-infected animals than in IAV mono-infected mice or in MHV-68 infected mice, respectively (data not shown). This type of cells is considered a major responding $\mathrm{T}$ cell subset in lungs of mice infected by various viruses or intracellular bacteria. They are also more rapid and effective producers of IL-17 in early stages of infection than $\mathrm{CD} 4^{+} \mathrm{T}$ cells (Cowley et al., 2010; Lin et al., 2009; D'Acquisto and Crompton, 2011).

Significant increase in the amount of neutrophils in peripheral blood of co-infected mice and notable elevation of Ly6G+/CD45+ neutrophils in lungs of double-infected mice in comparison with the single herpes-infected mice were observed at the $3^{\text {rd }}$ day of the acute influenza infection. Rate of neutrophils during co-infection had similar trend as seen in IAV mono-infected mice except for lungs, where during early stages after secondary IAV infection the number of neutrophils was markedly elevated but dropped rapidly before $6^{\text {th }}$ day p.i. with IAV when compared to single IAV infection. In contrast, the pool of $\mathrm{Ly} 6 \mathrm{G}^{+} / \mathrm{CD} 45^{+}$neutrophils in the spleen of double-infected mice had increased just mildly compared to the single herpesvirus infection. These results demonstrate that ongoing latent MHV-68 infection in co-infected mice affect the number of neutrophils in tissue/organ-dependent manner during acute IAV infection. Neutrophils are responsible for the pathological inflammatory infiltration and the necrosis. Many studies aiming to identify the roles of different subpopulation of leukocytes during the influenza infection were performed. In addition to macrophages and NK cells, neutrophils are also recruited into the lungs during influenza virus infection and play an important role in the immunopathology (Xu et al., 2006; Deng et al., 2010; Kostolanský et al., 2013). However, the role of neutrophils in influenza virus infection seems to be ambivalent. Two reports showed that the depletion of neutrophils before influenza virus infection resulted in higher mortality rates in mice (Ito et al., 2011; Fujisawa 2008), while other reports showed that increased numbers of neutrophils in lungs during influenza infection were associated with severe pneumonia and high mortality (Saito et al., 2013; Kostolanský et al., 2013; Perrone et al., 2008). The course of infection and the role of neutrophils within it appear to be dependent on the virus virulence. Our observations correspond to previous studies demonstrating that infection by influenza virus with mild and intermediate virulence leads to a transient weight loss of infected mice but they did not succumb to the infection. Pathogenesis is associated with the lung injury, however the recovery of the lung tissue and the clearance of the virus are not connected with an increased number of the neutrophils in the lungs and the alternative immune defense is sufficient to overcome the infection (Tate et al., 2011). The study of Saito $e t$ al. revealed lower numbers of neutrophils in lungs of MHV-68 and influenza virus co-infected mice, which is interpreted as a regulated neutrophil influx by the activated macrophages (Saito et al., 2013).

Titer of virus-neutralization antibodies against MHV-68 does not increase proportionally to the length of MHV-68 infection, but its level decreased proportionally with the time after the secondary influenza infection. Significantly decreased titer of antibodies against MHV-68 ranged from 4 to 32 . The maximum production of antibodies against MHV-68 was detected at the $1^{\text {st }}$ time point, which could be explained by the climax of the acute secondary influenza infection ongoing at that time.

Monitoring of the expression of ORF50 and ORF73 genes, the markers of lytic and latent phase of infection showed that their expression varied in individual samples and at various time points, despite the detection of herpesviral DNA almost in every sample throughout the duration of the experimental infection. At some intervals the difference between the expression of ORF50 and/or ORF73 in lungs of co-infected mice and herpes-infected mice was $50 \%$. It is unquestionable that the secondary influenza infection did not cause reactiva- 
tion of latent MHV-68, but surprisingly it led to a suppressed expression of selected MHV-68 genes. This can be a result of cap-snatching mechanism, which influenza virus uses for its replication and which leads to degradation of mRNAs other than influenza virus ones. This process can affect the MHV-68 gene expression in the cells that can be infected with both viruses, such as macrophages (alveolar and peritoneal) and epithelial cells (Rodger and Mims, 1981; Xie et al., 2009; Shih and Krug, 1996). It can result in the decreased number of MHV-68 transcripts to almost undetectable level. The inhibition of the ORF50 expression, which is the main trans-activator of the lytic genes, crucial for the reactivation from latency, can contribute to the attenuated reactivation of MHV-68 and its persistence in silent latent state (Virgin et al., 1997; Wu et al., 2000; Damania et al., 2004; Ebrahimi et al., 2003). Besides a transcript degradation, IAV acute infection is responsible for the apoptosis of a portion of host macrophages and lymphocytes what can also lead to a decrease in the number of the MHV-68 transcripts and to the reduction of its latent reservoir (Nichols et al., 2001). Prevention of reactivation is also ensured, as was mentioned above, by the $\mathrm{CD}^{+} \mathrm{T}$ cells, the production of cytokines, mainly IFN- $\gamma$ and the antibodies (Reese et al., 2014; Kim et al., 2002).

Based on our results, it is obvious that the concurrent latent herpesvirus infection and acute influenza co-infection affect numerous parameters of the host immune response. IAV infection did not lead to the reactivation of the latent MHV-68 and in cooperation with the host immune system suppressed the expression of the herpesvirus genes to a nearly undetectable level. This phenomenon could be observed mainly in lungs and PECs. Similarly, in other studies dealing with co-infection of MHV-68 and other pathogens, different course of disease, in comparison with the individual infections, was detected. Mice latently infected with MHV-68 followed by acute malaria did not develop any signs of infection during the experiment (Haque et al., 2004). In other studies it has been reported that MHV-68 latency modulates the host immune response to influenza A virus (Saito et al., 2013).

Acknowledgement. This paper is published thanks to the financial support of the projects: Grant UK No. UK/115/2014, Grants VEGA from the Scientific Grant Agency of the Ministry of Education of the Slovak Republic and Slovak Academy of Sciences: VEGA No. 1/0617/15, VEGA No. 2/0146/15, VEGA No. 2/0100/13, Grant from The Slovak Research and Development Agency under the contract No. APVV-0250-10. The authors would like to thank Dr. P. Ditte for his technical and analytical assistance.

\section{References}

Arfelt KN, Fares S, Rosenkilde MM (2015): EBV, the human host, and the 7TM receptors: defense or offense? Prog. Mol.
Biol. Trans. Sci. 129, 395-427. http://dx.doi.org/10.1016/ bs.pmbts.2014.10.011

Blaškovič D, Stančeková M, Svobodová J, Mistríková J (1980): Isolation of five strains of herpesviruses from two species of freeliving small rodents. Acta Virol. 24, 468.

Barton ES, White DW, Cathelyn JS, Brett-McClellan KA, Engle M, Diamond MS, Miller VL, Virgin HW 4th (2007): Herpesvirus latency confers symbiotic protection from bacterial infection. Nature 447, 326-329. http://dx.doi. org/10.1038/nature05762

Barton ES, Rajkarnikar S, Langston PK, Price MJ, Grayson JM (2014): Gammaherpesvirus latency differentially impacts the generation of primary versus secondary memory CD8(+) T cells during subsequent infection. J. Virol. 88, 12740-12751. http://dx.doi.org/10.1128/JVI.02106-14

Brooker SJ, Pullan RL, Gitonga CW, Ashton RA, Kolaczinski JH, Kabatereine NB, Snow RW (2012): Plasmodium-helminth coinfection and its sources of heterogeneity across East Africa. J. Infect. Dis. 205, 841-852. http://dx.doi. org/10.1093/infdis/jir844

Cárdenas-Mondragón MG, Carreón-Talavera R, CamorlingaPonce M, Gomez-Delgado A, Torres J, Fuentes-Pananá EM (2013): Epstein-Barr virus and Helicobacter pylori co-infection are positively associated with severe gastritis in pediatric patients. PLoS One 8, e62850. http://dx.doi. org/10.1371/journal.pone.0062850

Chen HD, Fraire AE, Joris I, Welsh RM, Selin LK (2003): Specific history of heterologous virus infections determines antiviral immunity and imunnopathology in the lung. A. M. J. Pathol. 163, 1341-1355. http://dx.doi.org/10.1016/ $\underline{\text { S0002-9440(10)63493-1 }}$

Clute SC, Watkin LB, Cornberg M, Naumov YN, Sullivan JL, Luzuriaga K, Welsh RM, Selin LK (2005): Cross-reactive influenza virus-specific CD8+ T cells contribute to lymphoproliferation in Epstein-Barr virus-associated infectious mononucleosis. J. Clin. Invest. 115, 3602-3612. http://dx.doi.org/10.1172/JCI25078

Cowley SC, Meierovics AI, Frelinger JA, Iwakura Y, Elkins KL (2010): Lung CD4-CD8-double-negative T cells are prominent producers of IL-17A and IFN-gamma during primary respiratory murine infection with Francisella tularensis live vaccine strain. J. Immunol. 184, 5791-5801. http://dx.doi.org/10.4049/jimmunol.1000362

D'Acquisto F, Crompton T (2011): CD3+CD4-CD8- (double negative) T cells: Saviours or villains of the immune response? Biochem. Pharm. 82, 333-340. http://dx.doi. org/10.1016/j.bcp.2011.05.019

Damania B, Jeong JH, Bowser BS, DeWire SM, Staudt MR, Dittmer DP (2004): Comparison of the Rta/Orf50 transactivator proteins of gamma-2-herpesviruses. J. Virol. 78, 5491-5499. http://dx.doi.org/10.1128/JVI.78.10.5491$\underline{5499.2004}$

De Lima BD, May JS, Marques S, Simas JP, Stevenson PG (2005): Murine gammaherpesvirus $68 \mathrm{bcl}-2$ homologue contributes to latency establishment in vivo. J. Gen. Virol. 86, 31-40. http://dx.doi.org/10.1099/vir.0.80480-0

Deng G, Bi J, Kong X, Li Q, Dong J, Zhang M, Zhao L, Luan Z, Lv N. et al. (2010): Acute respiratory distress syndrome induced 
by H9N2 virus in mice. Arch. Virol. 155, 187-195. http:// dx.doi.org/10.1007/s00705-009-0560-0

Ebrahimi B, Dutia BM, Roberts KL, Garcia-Ramirez JJ, Dickinson P, Stewart JP, Ghazal P, Roy DJ, Nash AA (2003): Transcriptome profile of murine gammaherpesvirus-68 lyticinfection. J. Gen. Virol. 84, 99-109. http://dx.doi. org/10.1099/vir.0.18639-0

Florescu DF, Mindru C, Chambers HE, Kalil AC (2011): Clostridium difficile and cytomegalovirus colitis co-infection: search for the hidden bug". Transpl. Infect. Dis. 13, 411-415. http://dx.doi.org/10.1111/j.1399-3062.2011.00605.x

Fislová T, Gocník M, Sládková T, Ďurmanová V, Rajčáni J, Varečková E, Mucha V, Kostolanský F (2009): Multiorgan distribution of human influenza A virus strain observed in a mouse model. Acta Virol. 154, 409-419. http://dx.doi. org/10.1007/s00705-009-0318-8

Fujinami RS, von Herrath MG, Christens U, Whitton JL (2006): Molecular mimicry, bystander activation, or viral persistence: infections and autoimmune disease. Clin. Microbiol. Rev. 19, 80-94. http://dx.doi.org/10.1128/ CMR.19.1.80-94.2006

Fujisawa $\overline{\mathrm{H} \text { (2008): Neutrophils play an essential role in coopera- }}$ tion with antibody in both protection against and recovery from pulmonary infection with influenza virus in mice. J. Virol. 82, 2772-2783. http://dx.doi.org/10.1128/ IVI.01210-07

Griffiths EC, Pedersen AB, Fenton A, Petchey OL (2011): The nature and consequences of coinfection in humans. J. Infect. 63, 200-206. http://dx.doi.org/10.1016/j.jinf.2011.06.005

Hardisty G, Nicol Mc Q, Ligertwood Y, Bryson K, Hopkins J, Dutia BM (2013): Acute Influenza A pathogenesis is ameliorated in murine model of latent gammaherpesvirus infection. Immunology 140 (Suppl. 1), 39-184.

Haque A, Rachinel N, Quddus MR, Haque S, Kasper LH, Usherwood E (2004): Co-infection of malaria and $\gamma$-herpesvirus: exacerbated lung inflammation or crossprotection depends on the stage of viral infection. Clin. Exp. Immunol. 138, 396-404. http://dx.doi.org/10.1111/ j.1365-2249.2004.02652.x

Hopwood P, Crawford DH (2000): The role of EBV in post-transplant malignancies: a review. J. Clin. Pathol. 53, 248-254. http://dx.doi.org/10.1136/jcp.53.4.248

Ito T, Allen RM, Carson WF, Schaller M, Cavassani KA, Hogaboam CM, Lukacs NW, Matsukawa A, Kunkel SL (2011): The critical role of Notch ligand delta-likelin the pathogenesis of influenza A virus (H1N1) infection. PLoS Pathogens 7, e1002341. http://dx.doi.org/10.1371/journal. ppat. 1002341

Kim I, Fla-o E, Woodland DL, Blackman M.A (2002): AntibodyMediated Control of Persistent $\gamma$-Herpes virus Infection. J. Immunol. 168, 958-3964. http://dx.doi.org/10.4049/ jimmunol.168.8.3958

Kostolanský F, Dugovičová V, Janulíková J, Mucha V, Mistríková J, Varečková E (2013): Virus dose-dependent neutrophil and lymphocyte proportions in peripheral blood during influenza A infection of mice. Acta Virol. 57, 474-476. http://dx.doi.org/10.4149/av $2013 \quad 04 \quad 474$
Kúdelová M, Rajčáni J (2007): Gammaherpesviruses and Oncogenesis. In Johannes LT (Ed): Oncogenic Viruses Research Trends. Chapter 8, Nova Science Publishers, ISBN 9781-6002-628-2.

Lin Y, Ritchea S, Logar A, Slight S, Messmer M, Rangel-Moreno J, Guglani L, Alcorn JF, Strawbridge H, Park SM, Onishi R, Nyugen N, Walter MJ, Pociask D, Randall TD, Gaffen SL, Iwakura Y, Kolls JK, Khader SA (2009): Interleukin-17 is required for $\mathrm{T}$ helper 1 cell immunity and host resistance to the intracellular pathogen Francisella tularensis. Immunity 31, 799-810. http://dx.doi.org/10.1016/j. immuni.2009.08.025

Mathurin KS, Martens H, Kornfeld H, Welsh RM (2009): CD4 T-cell-mediated heterologous immunity between mycobacteria and poxviruses. J. Virol. 83, 3528-3539. http:// dx.doi.org/10.1128/JVI.02393-08

Mutalima N, Molyneux E, Jaffe H, Kamiza S, Borgstein E, Mkandawire N, Liomba G, Batumba M et al. (2008): Associations between Burkitt lymphoma among children in Malawi and infection with HIV, EBV and malaria: results from a case-control study. PLoS One 3, e2505. http:// dx.doi.org/10.1371/journal.pone.0002505

Nash AA, Dutia BM, Stewart JP, Davison AJ (2001): Natural history of murine gammaherpesvirus infection. Philos. Trans. R. Soc. Lond. B. Biol. Sci. 356, 569-579. http://dx.doi. org/10.1098/rstb.2000.0779

Nichols JE, Niles JA, Roberts NJ (2001): Human lymphocyte apoptosis after exposure to Influenza A virus, J. Virol. 75, 5921-5929. http://dx.doi.org/10.1128/JVI.73.13.5921-5929.2001

Perrone LA, Plowden JK, Garcia-Sastre A, Katz JM, Tumpey TM (2008): H5N1 and 1918 pandemic influenza virus infection results in early and excessive infiltration of macrophages and neutrophils in the lungs of mice. PLoS Pathogens 4, e1000115. http://dx.doi.org/10.1371/journal. ppat. 1000115

Polčicová K, Hrabovská Z, Mistríková J, Tomášková J, Pastorek J, Pastoreková S, Kopáček J (2008): Up regulation of Murid herpesvirus 4 ORF 50 by hypoxia: Possible implication for virus reactivation from latency. Virus Res. 132, 257-262. http://dx.doi.org/10.1016/j.virusres.2007.12.004

Reese TA, Wakeman BS, Choi HS, Hufford MM, Huang SC, Zhang X, Buck MD, Jezewski A, Kambal A, Liu CY, Goel G, Murray PJ, Xavier RJ, Kaplan MH, Renne R, Speck SH, Artyomov MN, Pearce EJ, Virgin HW (2014): Coinfection. Helminth infection reactivates latent $\gamma$-herpesvirus via cytokine competition at a viral promoter. Science 345 , 573-577. http://dx.doi.org/10.1126/science.1254517

Rickinson AB, Kieff E (2007): Epstein-Barrvirus: In vypisat mena editorov Fields Virology. Philadelphia : Lippincott Williams \& Wilkins, pp. 2656-2700. ISBN 07-817-6060-7.

Rodger B, Mims CA (1981): Interaction of influenza virus with mouse macrophages. Infect. Immun. 31, 751-757.

Saito F, Ito T, Connett JM, Schaller MA, Carson WF, Hogaboam CM, Rochford R, Kunkel SL (2013): MHV68 latency modulates the host immune response to Influenza A virus. Inflammation 36, 1295-1303. http://dx.doi.org/10.1007/ $\underline{\text { s10753-013-9668-1 }}$ 
Selin LK, Varga SM, Wong IC, Welsh RM (1998): Protective heterologous antiviral imunity and enhanced immuno pathogenesis mediated by memory $\mathrm{T}$ cell populations. J. Exp. Med. 188, 1705-1715. http://dx.doi.org/10.1084/ jem.188.9.1705

Sharma S, Thomas PG (2014): The two faces of heterologous immunity: protection or immunopathology. J. Leuk. Biol. 95, 1-12. http://dx.doi.org/10.1016/j. biologicals.2013.11.001

Shih S, Krug R.M (1996): Surprising function of the three influenza viral polymerase proteins: selective protection of viral mRNAs against the cap-snatching reaction catalyzed by the same polymerase proteins. Virology 226, 430-435. http://dx.doi.org/10.1006/viro.1996.0673

Smith AM, Adler FR, Ribeiro RM, Gutenkunst RN, McAuley JL, McCullers JA, Perelson AS (2013): Kinetics of coinfection with influenza A virus and Streptococcus pneumoniae. PLoS Pathog. 9, e1003238. http://dx.doi.org/10.1371/ journal.ppat.1003238

Tate MD, Ioannidis LJ, Crocker B, Brown LE, Brooks AG, Reading PC (2011): The Role of neutrophils during mild and severe Influenza virus infections of mice. PLoS ONE 6, e17618. http://dx.doi.org/10.1371/journal.pone.0017618

Thakar J, Pathak AK, Murphy L, Albert R, Cattadori IM (2012): Network model of immune responses reveals key effectors to single and co-infection dynamics by a respiratory bacterium and a gastrointestinal helminth. De Boer RJ, ed. PLoS Comput. Biol. 8, e1002345. http://dx.doi. org/10.1371/journal.pcbi. 1002345
Virgin HW, Latreille P, Wamsley P, Hallsworth K, Weck KE, Dal Canto AJ, Speck SH (1997): Complete sequence and genomic analysis of murine gammaherpesvirus 68. J. Virol. 71, 5894-5904.

Welsh RM, Fujinami RS (2007): Pathogenic epitopes, heterologous immunity and vaccine design. Nat. Rev. Microbiol. 5, 555-563. http://dx.doi.org/10.1038/nrmicro1709

Welsh RM, Che JW, Brehm MA, Selin LK (2010): Heterologous immunity between viruses. Immunol. Rev. 235, 244-266. http://dx.doi.org/10.1111/j.0105-2896.2010.00897.x

Wu TT, Usherwood EJ, Stewart JP, Nash AA, Sun R (2000): Rta of murine gammaherpesvirus 68 reactivates the complete lytic cycle from latency. J. Virol. 74, 3659-3667. http:// dx.doi.org/10.1128/JVI.74.8.3659-3667.2000

Xie D, Bai H, Liu L, Xie X, Ayello J, Ma X, Zhang J (2009): Apoptosis of lymphocytes and monocytes infected with influenza virus might be the mechanism of combating virus and causing secondary infection by influenza, Int. Immunol. 21, 1251-1262. http://dx.doi.org/10.1093/intimm/dxp087

Xu T, Qiao J, Zhao L, Wang G, He G, Li K, Tian Y, Gao M, Wang J, Wang H (2006): Acute respiratory distress syndrome induced by avian influenza A (H5N1) virus in mice. Am. J. Resp. Crit. Care Med. 174, 1011-1017. http://dx.doi. org/10.1164/rccm.200511-17510C

Yager EJ, Szaba FM, Kummer LW, Lanzer KG, Burkum CE, Smiley ST, Blackman MA (2009): Gammaherpesvirus-induced protection against bacterial infection is transient. Viral Immunol. 22, 67-72. http://dx.doi.org/10.1089/ $\underline{\text { vim. } 2008.0086}$ 